\title{
The Influence of Side Friction on Speed-Mixed Flow Behavior on Arterial Roads in Tourism Area in Bali
}

\author{
D. M Priyantha Wedagama ${ }^{1, *}$, I Wayan Suweda ${ }^{1}$, N. L. G Astariyani² \\ ${ }^{1}$ Department of Civil Engineering, Udayana University, Bukit Jimbaran, 80361, Bali, Indonesia \\ ${ }^{2}$ Faculty of Law, Udayana University, Bukit Jimbaran, 80361, Bali, Indonesia
}

Received August 23, 2021; Revised November 8, 2021; Accepted December 13, 2021

\begin{abstract}
Cite This Paper in the following Citation Styles
(a): [1] D. M Priyantha Wedagama, I Wayan Suweda, N. L. G Astariyani, "The Influence of Side Friction on Speed-Mixed Flow Behavior on Arterial Roads in Tourism Area in Bali," Civil Engineering and Architecture, Vol. 10, No. 1, pp. 27 - 44, 2022. DOI: 10.13189/cea.2022.100103.
\end{abstract}

(b): D. M Priyantha Wedagama, I Wayan Suweda, N. L. G Astariyani (2022). The Influence of Side Friction on Speed-Mixed Flow Behavior on Arterial Roads in Tourism Area in Bali. Civil Engineering and Architecture, 10(1), 27 44. DOI: 10.13189/cea.2022.100103.

Copyright $\odot 2022$ by authors, all rights reserved. Authors agree that this article remains permanently open access under the terms of the Creative Commons Attribution License 4.0 International License

\begin{abstract}
The arterial roads in tourism areas show a lack of control over activities that occur on the arterial roadsides. This study constructs a speed-flow behavior model to analyze the influence of side friction events under mixed traffic flows on arterial road performances in Bali. This event is dominated by the entry and exit of vehicles from road access points. The study results show that in friction conditions, the speed of the motorcycle is significantly affected by the presence and speed of other motorcycles and light vehicles, but in base conditions, it is significantly affected by the presence and speed of all types of vehicles. Meanwhile, the speed of light vehicles is significantly influenced by the presence and speed of motorcycles and other light vehicles. A further study is required to analyze the influence of motorized vehicles on the selection of heavy vehicle speed on arterial roads. Due to side frictions, a decrease in road capacity (pcu/hour) was found between $14.37 \%$ and $26.60 \%$ while a decrease in speed was between $13.79 \%$ and $76.19 \%$. These show a significant side friction problem on arterial roads in tourism areas. The road control policy, particularly on roadside access is needed for these arterial roads.
\end{abstract}

Keywords Arterial Roads, Mixed Traffic, Side Friction, Speed-Flow Behavior, Tourism Area

\section{Introduction}

Based on the road hierarchy, an arterial road is to serve major transportation with the characteristics of long-distance trips, high average speeds, and the number of access points on the roads is efficiently limited $[1,2]$. Arterial roads are high-capacity urban roads connecting traffic flows from lower road functions (collector and local) to higher (toll roads) and vice versa [3]. Traffic on arterial roads should also not be disturbed by slow traffics caused by roadside activities $[1,2]$. This indicates that the urban road hierarchy has a significant impact on the effectiveness of transportation and traffic management systems in urban areas [3, 4]

Based on observations, there is a lack of control over activities that occur on the arterial roadsides in the tourism area in Bali, such as on-street parking, entry, and exit of vehicles from the surroundings. In many locations, the traffic does not maintain its mobility characteristics due to roadside activity factors or what is referred to as side friction factors. The impact of these side frictions on the capacity of arterial roads must be analyzed for policy and technical improvements to improve the performance of arterial roads, especially the relation between traffic flow and speed $[5,6]$.

Meanwhile, several previous studies [7-11] show that the methods of determining the road segment capacity used in developed countries do not reflect conditions in developing countries. They do not take into account the characteristics of mixed traffic flows, such as in Indonesia where the traffic is dominated by motorcycles. In addition, speed data distribution follows the normal distribution in homogeneous traffic conditions in developed countries but 
they do not under heterogeneous/mixed traffic [7]. In Indonesia, technical guidelines for determining road and intersection capacity refer to the Indonesian Road Capacity Manual (MKJI) [12]. However, due to the high proportion of motorcycles in Indonesia, including in Bali Province, which exceeds $85 \%$ [13], MKJI is deemed inadequate as a reference in the analysis of road performance [14].

This previous study [14] aimed to improve the formulation of MKJI in particular free-flow speed and initial capacity. Traffic data were obtained from various four-lane roads with dividers in several cities in Indonesia. The data is then simulated using the simulation model software of VISSIM. The measured speeds and headways are compared to the simulation results. There is no significant difference between measured speed and headway and the simulation results. After calibration, the speed-flow relationship is compared to the MKJI formula, simulating various traffic flows. The results showed that the value of free-flow speed and basic capacity needed to be verified.

The MKJI is still oriented towards light vehicles as a reference for mixed traffic flow conditions which are dominated by motorcycles. Therefore, it is hoped that the determination of the motorcycle equivalent value and the analysis of the speed-flow model can be used to evaluate the road performances, especially for mixed traffic conditions. This study, therefore, prepares an alternative model besides the use of MKJI to analyze the effect of side friction on the performance of arterial roads. This study aims to analyze the speed-flow behavior due to arterial roadside friction under mixed traffic flows. This side friction may reduce the overall road performance. This research was conducted on three arterial road segments (divided highways with a four-lane-two-way or 4/2 D) in a tourism area in Bali as the case study.

Depending on the area, such as business centers/city centers, cities, and suburbs, the intensity and types of activities that cause side frictions are noted. Generally, side frictions are classified as follows [15]:

1. Activities that occur on the way:

a) public transports stop at the bus stop due to the activity of alighting and boarding of passengers

b) non-motorized vehicles such as wheelbarrows pedestrians and cyclists

c) slow-moving vehicle or vehicles intend to park

d) pedestrians cross the road.

2. Activities on road shoulder :
a) parked or stopped vehicles such as public transports
b) parked damaged vehicles
c) pedestrians, bicycles, and non-motorized vehicles use road shoulders.
d) street beggars and merchants

3. Side frictions to road shoulder and access: a) access points and entrances to roadside shops, schools, gas stations, etc.

b) trading activities including food stalls, kiosks, etc.

The impact of a combination of these factors on the characteristics of the mixed traffic flow is analyzed quantitatively. Given that in mixed traffic flow, the transportation modes vary consist of motorcycle (MC), light vehicles (LV), and heavy vehicles (HV), the specific objectives of this study are:

a) to analyze the value of passenger cars equivalent (PCE) of light vehicles as a standard.

b) to develop speed models which are used to analyze the influence of each type of vehicle on the speed of each vehicle on arterial roads in tourism areas

c) to analyze the performance of urban road parameters based on the speed-flow behavior under mixed traffic flows conditions.

Previous studies have also been carried out in several developing countries that have mixed traffic flows, such as in India, Vietnam, and Malaysia [7-11, 16]. The difference between this study and these studies lies in the road traffic characteristics while the proportion of motorcycles is not as high as in Indonesia.

The study results on speed-flow behavior due to arterial roadside friction parameters are expected to better reflect the real condition of the performance of arterial roads for mixed traffic conditions which are dominated by motorcycles. In addition, the results are expected to contribute as a reference in the formulation of policies or regulations in the field of land transport traffic, especially on arterial roads, to maximize passenger mobility and logistics on arterial roads. The policy formulation in question has not yet been implemented on arterial roads in tourist destinations in Bali, including:

a) The speed limit in urban areas in Bali Province. The upper and lower limits of traffic speeds do not yet exist on arterial roads in Bali.

b) Control policy on-street parking, parked and stopped along the arterial roads. Parking or stopping on the arterial road greatly affects the speed and performance of arterial roads.

c) Control policy for entry and exit of motorized vehicles from the road access points.

\section{Materials and Methods}

\subsection{Why Passenger Car Equivalent is Required?}

Currently, road section capacity is determined using the Indonesian Road Capacity Manual (MKJI) published in 1997 [12]. At that time the traffic conditions were different from the number or proportion of motorcycles, unlike today. The number of motorcycles in 1997 in Bali Province was 494,057 units, while in 2017 it had reached 3,337,326 
units [13]. There has been an increase of almost 6.75 times the number of motorcycles in the 20 years in Bali Province. Vehicle size and motorcyclist behavior can reduce the speed of other modes of transportation and can increase traffic flow delays on roads $[17,18]$. This of course can reduce the service level of these roads.

On the other hand, different conditions occur in developed countries where traffic tends to be homogeneous, consisting of only heavy and light vehicles. Even heavy vehicles are restricted in their movement to enter urban areas so that only light vehicles dominate in urban areas. In addition, there are strict restrictions for motorized vehicles, namely that they must travel in their respective lane (lane discipline). This condition is rarely found in mixed traffic in developing countries such as Indonesia. For example, most motorcyclists ride on a road and stop at the red traffic light, not on the provided lane.

Based on this, the passenger car equivalent (PCE) value, used for the conversion of several types of motorized vehicles in Indonesia (including in Bali Province) should be determined based on the composition (type and proportion) of motorized vehicles in the traffic flow. This PCE value plays an important role in determining the value of the road segment capacity. There are various methods for determining the PCE value of motorized vehicles, such as the homogenization coefficient method, the Walker method, the Headway method, the multiple linear regression method, and the simulation technique [3]. This study uses the approach from previous studies [17, 18] because the method is simpler and takes into account the horizontally projected dimensions of motorized vehicles and vehicle speed which are the main characteristics of motorized vehicles for mixed traffic conditions. This method is hereinafter referred to as the dynamic equivalent factor or dynamic car unit.

Dynamic equivalent factors include the effect of vehicle speed on traffic. The speed and maneuverability of motorized vehicles in a traffic flow are determined by motor vehicles that have a high proportion such as motorcycles. In this study, the vehicle dynamic equivalent factor was determined using a light vehicle as the reference vehicle. The static characteristic effect of motorized vehicles is determined by the area ratio, namely the ratio of the projected area of the reference vehicle and other vehicles. Meanwhile, the speed ratio is described as the ratio of the reference vehicle speed to other vehicle types to include the effect of the difference in speed as a dynamic characteristic. It can be noted that the area ratio remains constant for all vehicle types, whereas the speed ratio varies dynamically as follows [3]:

$$
\mathrm{DEF}_{\mathrm{c}}=\frac{V_{m c} / V_{i}}{A_{m c} / A_{i}}
$$

where,
$\mathrm{DEF}_{\mathrm{c}}$ : Dynamic equivalent factor value for type $\mathrm{i}$ of a mode of transport.
$\mathrm{V}_{\mathrm{mc}}$ : The average speed of light vehicles as reference $(\mathrm{km} / \mathrm{h})$
$\mathrm{V}_{\mathrm{i}}$ : The average speed of type $\mathrm{i}$ of a mode of transport $(\mathrm{km} / \mathrm{h})$
$\mathrm{A}_{\mathrm{mc}}$ : The area (length $\mathrm{x}$ width) of a light vehicle as a reference $\left(\mathrm{m}^{2}\right)$
$\mathrm{A}_{\mathrm{i}}$ : Area (length $\mathrm{x}$ width) of type $\mathrm{i}$ of a mode of transport on the highway $\left(\mathrm{m}^{2}\right)$

Considering its maneuverability, the motorcycle moves on the road, not in the available lane. In traffic with per lane rules, the occupancy of vehicles on the road is controlled by the length of the vehicle which is then used to determine the passenger car unit (PCU) [17]. However, in conditions where the vehicle is moving not on its lane, occupancy is better expressed in units of area. The tabulations of the vehicle categories with their average dimensions are shown in Table 1. The planned vehicle category includes small, medium, and large vehicles taken from the Guidelines for Geometric Planning Procedures for Inter-City Roads [19] while the motorcycle category follows a past study [17].

Table 1. Vehicle Categories and Dimensions

\begin{tabular}{cccc}
\hline Type & Vehicle & $\begin{array}{c}\text { Dimension } \\
(\mathbf{m})\end{array}$ & $\begin{array}{c}\text { Area } \\
\left(\mathbf{m}^{2}\right)\end{array}$ \\
\hline Small Vehicle & Passenger car & $2.1 \times 5.8$ & 12.18 \\
Medium Vehicle & $\begin{array}{c}\text { Truck and bus } \\
\text { with 2 axles }\end{array}$ & $2.6 \times 12.10$ & 31.46 \\
Large Vehicle & Truck-semi trailer & $2.6 \times 21.00$ & 54.6 \\
Motorcycle & Scooter, motorcycle & $1.87 \times 0.64$ & 1.2 \\
\hline
\end{tabular}

\subsection{Speed-Flow Relationship}

Traffic flow theory describes the relationships among traffic flow, density, and speed. Greenshield studied the relationship of traffic flow and proposed a linear function between speed and traffic density [17, 20]. Traffic flow behavior is calculated using the relationship between speed-density, speed(V)-flow(Q), and flow(Q)-density(K) in a macroscopic approach. In this study, the behavior of traffic flows on urban arterial roads is analyzed in heterogeneous traffic conditions. The model is developed by considering the characteristics of traffic flow (vehicle/hour), speed (km/hour), and density (vehicle/km). Traffic data with and without roadside frictions were observed on the roads and the traffic speed behavior was modeled using the Greenshields model. The general speed-density relationship is as follows:

$$
\mathrm{Q}=(\mathrm{A}-\mathrm{B} * \mathrm{~K}) * \mathrm{~K} \text { or } \mathrm{Q}=\mathrm{A} * \mathrm{~K}-\mathrm{B} * \mathrm{~K}^{2}
$$

where

$\mathrm{Q}=$ flow (vehicle/hour); $\mathrm{A}, \mathrm{B}=$ constant;

$\mathrm{K}=$ density (vehicle $/ \mathrm{km}$ ).

Based on the Q-K-V relationship, density can be 
determined using flow and speed data. The shape of the Q-K and Q-V relationship, the density, and the free flow speed can be determined. With (2) different densities and speeds $(0 \%$ to $100 \%)$, the flow is calculated for a road segment with less congestion. The maximum capacity/flow for each type of vehicle on this road is obtained by arranging the density-speed function so that the maximum flow-speed curve at the point where the saturation flow begins can be determined. Density describes the proximity between motorized vehicles and maneuvers in traffic flow. In contrast to speed, density is influenced by the level of traffic flow [21]. The Greenshields model can therefore be used regardless of the speed-flow-density portion [17, 20].

\subsection{Data Collection}

The traffic data was collected at three (3) road segments with and without side frictions on Bypass Ngurah Rai which connects the capital city of Denpasar and tourist destination areas in southern Bali. A total of six (6) segments of the road were selected, considering the presence of various traffic flow conditions such as intensity (volume-capacity ratio), traffic distribution, traffic composition, and level of side friction (present/absent). The location is not close to the intersection because the intersection is prone to congestion. This is avoided because the idea is to observe uninterrupted flows. In addition, roads are selected based on the physical and geometric qualities that can support such studies. While road selection is generally based on physical, environmental, and traffic conditions, road segment selection is based on more specific requirements, namely straight, flat road segments $(0 \%$ slope). The observed road segments are shown in Table 2.

Traffic data includes traffic volume and speed of each type of vehicle, namely motorcycles, light, and heavy vehicles. Traffic data collection at locations is carried out by marking reference lines on roads. Video cameras are placed on the left and right of the road so that they can record the accompaniment of vehicles crossing the observation point. Traffic volume is determined by counting the number of vehicles for each five-minute counting period to take into account variations in flow and speed due to the heterogeneous nature of traffic. This procedure is carried out for all vehicle categories.

To measure speed, data were collected through a graphic video survey and vehicle exit time at a distance of $10 \mathrm{~m}$ marked in the field also for every 5-minute interval. Time is recorded to two decimal places (in seconds) to achieve the desired level of precision in data extraction. The value of traffic speed is obtained by dividing the observation distance $(10 \mathrm{~m})$ by the travel time data (seconds). At the time of this observation, the dominant position of the vehicle in the lane was also seen. Vehicles that are considered dominant in certain lanes (more than $50 \%$ of the vehicle width) are included in that lane and are not used on other lanes. Not all vehicles can take the travel time, therefore sampling is carried out with several criteria that serve to represent the travel time data. The selection criteria consist of (a) vehicles that are recorded for travel time must be completely visible without being obstructed by other vehicles when the front wheel crosses the line of sight, (b) in an accompanying vehicle, the travel time recorded is the travel time of the leading vehicle, and (c) for vehicles that are preparing on the observation path, the travel time is not counted.

Table 2. Observed Road Segments

\begin{tabular}{|c|c|c|c|c|}
\hline \multirow{2}{*}{ Road Segments } & \multirow{2}{*}{$\begin{array}{l}\text { Coordinates } \\
\text { \& time of } \\
\text { observation }\end{array}$} & \multicolumn{3}{|c|}{ Road Geometry } \\
\hline & & Type & Width (m) & Median \\
\hline $\begin{array}{l}\text { Jl. Bypass Ngurah Rai (towards } \\
\text { Sanur) }\end{array}$ & $\begin{array}{c}8^{0} 42^{\prime} 15.17^{\prime \prime} ; 115^{0} 14^{\prime} 54.98^{\prime \prime} \\
25 / 07 / 2021 \\
07.30-10.30 \mathrm{hrs}\end{array}$ & Four-lane friction & 14.10 & Yes \\
\hline $\begin{array}{l}\text { J1. Bypass Ngurah Rai (towards } \\
\text { Kuta) }\end{array}$ & $\begin{array}{c}8^{0} 43^{\prime} 59.57^{\prime \prime} ; 115^{0} 14^{\prime} 54.98^{\prime \prime} \\
27 / 072021 \\
07.30-10.30 \mathrm{hrs}\end{array}$ & Four-lane friction & 14.50 & Yes \\
\hline $\begin{array}{l}\text { Jl. Bypass Ngurah Rai (towards } \\
\text { Nusa Dua) }\end{array}$ & $\begin{array}{c}8^{0} 47^{\prime} 6.77^{\prime} ; 115^{0} 11^{\prime} 55.43^{\prime \prime} \\
30 / 072021 \\
07.30-10.30 \mathrm{hrs} \\
\end{array}$ & Four-lane friction & 14.10 & Yes \\
\hline $\begin{array}{l}\text { Jl. Bypass Ngurah Rai (towards } \\
\text { Sanur) }\end{array}$ & $\begin{array}{c}8^{0} 42^{\prime} 15.12^{\prime \prime} ; 115^{0} 15^{\prime} 3.11^{\prime \prime} \\
25 / 07 / 2021 \\
07.30-10.30 \mathrm{hrs}\end{array}$ & Four-lane base & 14.10 & Yes \\
\hline $\begin{array}{l}\text { Jl. Bypass Ngurah Rai (towards } \\
\text { Kuta) }\end{array}$ & $\begin{array}{c}8^{0} 43^{\prime} 57.08^{\prime \prime} ; 115^{0} 10^{\prime} 42.94^{\prime \prime} \\
27 / 072021 \\
07.30-10.30 \mathrm{hrs} \\
\end{array}$ & Four-lane base & 14.50 & Yes \\
\hline $\begin{array}{l}\text { Jl. Bypass Ngurah Rai (towards } \\
\text { Nusa Dua) }\end{array}$ & $\begin{array}{c}8^{0} 47^{\prime} 6.11^{\prime \prime} ; 115^{0} 11^{\prime} 5.02^{\prime \prime} \\
30 / 072021 \\
07.30-10.30 \mathrm{hrs}\end{array}$ & Four-lane base & 14.10 & Yes \\
\hline
\end{tabular}


Traffic data collection is carried out not when the traffic flow is saturated at a non-congested time or over the capacity. Due to work safety reasons, data collection on road geometry (lane width, road, shoulder, and median) is carried out at low traffic conditions, at separate hours with traffic data measurements. With the traffic composition in the study location and the dominance of motorcycles, the traffic volume is converted to PCE using (1).

\section{Results and Discussion}

\subsection{Survey Results}

Table 3 shows the traffic characteristics of the observed road segments. Observations were made during the pandemic so that traffic conditions were lower than those during non-pandemic. The time of observation was carried out in the morning which was previously observed as the peak hour of traffic. Motorcycles have the largest proportion on the six (6) observation segments, between $61 \%$ and $78 \%$ followed by light vehicles in the range of $21 \%-34 \%$, and heavy vehicles in between $1 \%$ and $4.5 \%$. This proportion of transportation modes generally demonstrates mixed traffic flow conditions.

Pedestrians crossing the road or walking on the road, parked and stopped cars on the road shoulder, non-motorized vehicles passing by on the roadside, and vehicle entry and exit from the surroundings are among the side frictions examined. The side frictions were observed for 200 meters along the road. There are between 800 and 3600 events of side frictions observed from 7.30 to 10.30 a.m Bali local time. Based on data, the side friction event is dominated by entered and exited vehicles along with the road access as shown in Table 4 .

It is hard to measure traffic density on-site, in the field. Therefore, density ( $\mathrm{K}=\mathrm{vehicles} / \mathrm{observed}$ distance) can be derived from the ratio between the number of vehicles $(\mathrm{n}=$ vehicles/time interval) and speed (V=observed distance/time interval) [22]. Based on this, a relationship between speed and density was made for 5-minute intervals from $7.30-10.30$ a.m. Bali's local time is shown in Figure 1.

The relationship between speed and density is mostly a straight line whose significance level is shown by the value of the coefficient of determination $\mathrm{R}^{2}$ both with and without side frictions. There are three categories of vehicles in each condition, so there are $18 \mathrm{R}^{2}$ values. There are 13 out of a total of 18 (72\%) observations showing an $\mathrm{R}^{2}$ value greater than $50 \%$. Therefore, straight-line relationships of speed-density are considered to be fitted in all observed segments. The speed-density relationship as a straight line indicates that when the density increases, the vehicle speed will decrease.

Furthermore, it is also noted that there is a large variation in speed, even at the same current density. This speed variation is due to heterogeneity in the traffic mix. At the same speed, the traffic density may consist of motorcycles, or perhaps heavy vehicles. Due to the different operating conditions of small and large-sized vehicles, this speed variation is observed. If the speed-density relationship fits in a straight line, then the speed-flow relationship is appropriately described as a parabola [23].

Table 3. Traffic Composition on Selected Road Segment

\begin{tabular}{|c|c|c|c|c|}
\hline Road Segment & Road Type & Motorcycle & Light Vehicle & Heavy Vehicle \\
\hline $\begin{array}{c}\text { Jl. Bypass Ngurah Rai (towards } \\
\text { Sanur) }\end{array}$ & Four-lane friction & 3426 units (61.4\%) & 1903 units (34.1\%) & 248 units (4.5\%) \\
\hline $\begin{array}{c}\text { J1. Bypass Ngurah Rai (towards } \\
\text { Kuta) }\end{array}$ & Four-lane friction & 10165 units (72.1\%) & 3556 units (25.2\%) & 376 units (2.7\%) \\
\hline $\begin{array}{c}\text { Jl. Bypass Ngurah Rai (towards } \\
\text { Nusa Dua) }\end{array}$ & Four-lane friction & 4678 units (77.6\%) & 1278 units (21.2\%) & 74 units (1.2\%) \\
\hline $\begin{array}{c}\text { Jl. Bypass Ngurah Rai (towards } \\
\text { Sanur) }\end{array}$ & Four-lane base & 4855 units (64.8\%) & 2364 units (31.6\%) & 271 units (3.6\%) \\
\hline $\begin{array}{c}\text { Jl. Bypass Ngurah Rai (towards } \\
\text { Kuta) }\end{array}$ & Four-lane base & 10401 units (72.1\%) & 3657 units (25.3\%) & 376 units (2.6\%) \\
\hline $\begin{array}{c}\text { Jl. Bypass Ngurah Rai (towards } \\
\text { Nusa Dua) }\end{array}$ & Four-lane base & 5648 units (78.0\%) & 1517 units (21.0\%) & 70 units (1.0\%) \\
\hline
\end{tabular}

Table 4. Side Frictions on Selected Road Segment

\begin{tabular}{|c|c|c|c|c|c|}
\hline Road Segment & Pedes-trians & $\begin{array}{c}\text { Parked \& stopped } \\
\text { Vehicle }\end{array}$ & $\begin{array}{c}\text { Entry \& exit } \\
\text { vehicle }\end{array}$ & $\begin{array}{c}\text { Non-motorized } \\
\text { vehicle }\end{array}$ & Total \\
\hline $\begin{array}{c}\text { Jl. Bypass Ngurah Rai } \\
\text { towards Sanur) }\end{array}$ & $\begin{array}{c}13 \\
(1.58 \%)\end{array}$ & $\begin{array}{c}7 \\
(0.85 \%)\end{array}$ & $764(92.94 \%)$ & $\begin{array}{c}38 \\
(4.63 \%)\end{array}$ & 822 \\
\hline $\begin{array}{c}\text { Jl. Bypass Ngurah Rai } \\
\text { (towards Kuta) }\end{array}$ & $\begin{array}{c}8 \\
(0.75 \%)\end{array}$ & $\begin{array}{c}0 \\
(0 \%)\end{array}$ & $998(93.09 \%)$ & 66 \\
$(6.16 \%)$ & 1072 \\
\hline $\begin{array}{c}\text { Jl. Bypass Ngurah Rai } \\
\text { (towards Nusa Dua) }\end{array}$ & $\begin{array}{c}2 \\
(0.06 \%)\end{array}$ & $\begin{array}{c}2 \\
(0.06 \%)\end{array}$ & $3566(99.30 \%)$ & $\begin{array}{c}21 \\
(0.58 \%)\end{array}$ & 3591 \\
\hline
\end{tabular}


Table 5. Speed Spread Ratio

\begin{tabular}{|c|c|c|c|c|c|}
\hline Friction conditions & $\begin{array}{l}\text { Type of } \\
\text { Vehicle }\end{array}$ & $\mathbf{V}_{85}$ & $\mathbf{V}_{50}$ & $\mathbf{V}_{15}$ & $\begin{array}{c}\text { SSR } \\
\text { (Normal Distribution) } \\
\end{array}$ \\
\hline \multirow{3}{*}{$\begin{array}{l}\text { J1. Bypass Ngurah Rai } \\
\text { (towards Sanur) }\end{array}$} & MC & 32 & 20 & 10 & 1.16 (Yes) \\
\hline & LV & 34 & 23 & 7 & $0.67(\mathrm{No})$ \\
\hline & $\mathrm{HV}$ & 39 & 33 & 25 & 0.73 (No) \\
\hline \multirow{3}{*}{$\begin{array}{l}\text { Jl. Bypass Ngurah Rai } \\
\text { (towards Kuta) }\end{array}$} & MC & 38 & 30 & 20 & $0.88(\mathrm{No})$ \\
\hline & LV & 42 & 32 & 25 & 1.40 (Yes) \\
\hline & $\mathrm{HV}$ & 40 & 31 & 24 & 1.47 (Yes) \\
\hline \multirow{3}{*}{$\begin{array}{l}\text { Jl. Bypass Ngurah Rai } \\
\text { (towards Nusa Dua) }\end{array}$} & MC & 30 & 22 & 13 & 0.86 (No) \\
\hline & LV & 38 & 28 & 14 & 0.77 (No) \\
\hline & HV & 39 & 36 & 30 & 0.58 (No) \\
\hline Base conditions & $\begin{array}{l}\text { Type of } \\
\text { Vehicle }\end{array}$ & $\mathrm{V}_{85}$ & $\mathrm{~V}_{50}$ & $\mathrm{~V}_{15}$ & $\begin{array}{c}\text { SSR } \\
\text { (Normal Distribution) } \\
\end{array}$ \\
\hline \multirow{3}{*}{$\begin{array}{l}\text { J1. Bypass Ngurah Rai } \\
\text { (towards Sanur) }\end{array}$} & MC & 62 & 48 & 31 & 0.87 (No) \\
\hline & LV & 63 & 51 & 32 & $0.64(\mathrm{No})$ \\
\hline & HV & 57 & 46 & 33 & 0.78 (No) \\
\hline \multirow{3}{*}{$\begin{array}{l}\text { Jl. Bypass Ngurah Rai } \\
\text { (towards Kuta) }\end{array}$} & MC & 57 & 48 & 40 & 1.00 (Yes) \\
\hline & $\mathrm{LV}$ & 54 & 45 & 38 & $1.23(\mathrm{No})$ \\
\hline & $\mathrm{HV}$ & 48 & 39 & 34 & $1.65(\mathrm{No})$ \\
\hline \multirow{3}{*}{$\begin{array}{l}\text { Jl. Bypass Ngurah Rai } \\
\text { (towards Nusa Dua) }\end{array}$} & MC & 62 & 47 & 39 & $1.89(\mathrm{No})$ \\
\hline & $\mathrm{LV}$ & 56 & 44 & 38 & $1.87(\mathrm{No})$ \\
\hline & $\mathrm{HV}$ & 43 & 39 & 35 & $1.24(\mathrm{No})$ \\
\hline
\end{tabular}

Meanwhile, the Speed Spread Ratio (SSR) is defined as the ratio of the difference in $85^{\text {th }}$ and $50^{\text {th }}$ percentile speed to the difference in $50^{\text {th }}$ and $15^{\text {th }}$ percentile on a section [7].

$$
\mathrm{SSR}=\left(\mathrm{V}_{85}-\mathrm{V}_{50} / \mathrm{V}_{50}-\mathrm{V}_{15}\right)
$$

The vehicles having an SSR range between 0.89-1.16 follow the normal distribution. Two peaks are observed in the speed data.When SSR is either less than 0.89 or more than 1.16 [7]. The second peak occurs when either roadside frictions highly occurred or the speed of moving vehicles highly varied for base conditions.

Table 5 shows that the motorcycles on Jl. Bypass Ngurah Rai (towards Sanur) and light and heavy vehicles on Jl. Bypass Ngurah Rai (towards Kuta) were not influenced by side frictions so that the speed of these vehicles was normally distributed. Under base conditions, however, the speed of all vehicles varied on the arterial roads, but motorcycles on Jl. Bypass Ngurah Rai (towards Kuta).

\subsection{Linear Regression Model}

The speed of each vehicle depends on the total traffic density on the road which consists of the density of each vehicle on the road. Mathematically, for a traffic flow consisting of three categories of vehicles, the speed of a type of mode $\mathrm{i}$ is expressed with the density of each category of vehicles in mixed traffic expressed by [24]:

$$
\mathrm{V}_{\mathrm{i}}=\mathrm{a}_{\mathrm{oi}}-\mathrm{a}_{1} \cdot \mathrm{K}_{1}-\mathrm{a}_{2} \cdot \mathrm{K}_{2}-\mathrm{a}_{3} \cdot \mathrm{K}_{3}
$$

where,

$\mathrm{K}=$ density=flow $(\mathrm{Q})$ of vehicle $\mathrm{i} /$ speed $(\mathrm{V})$ of vehicle $\mathrm{i}$ 

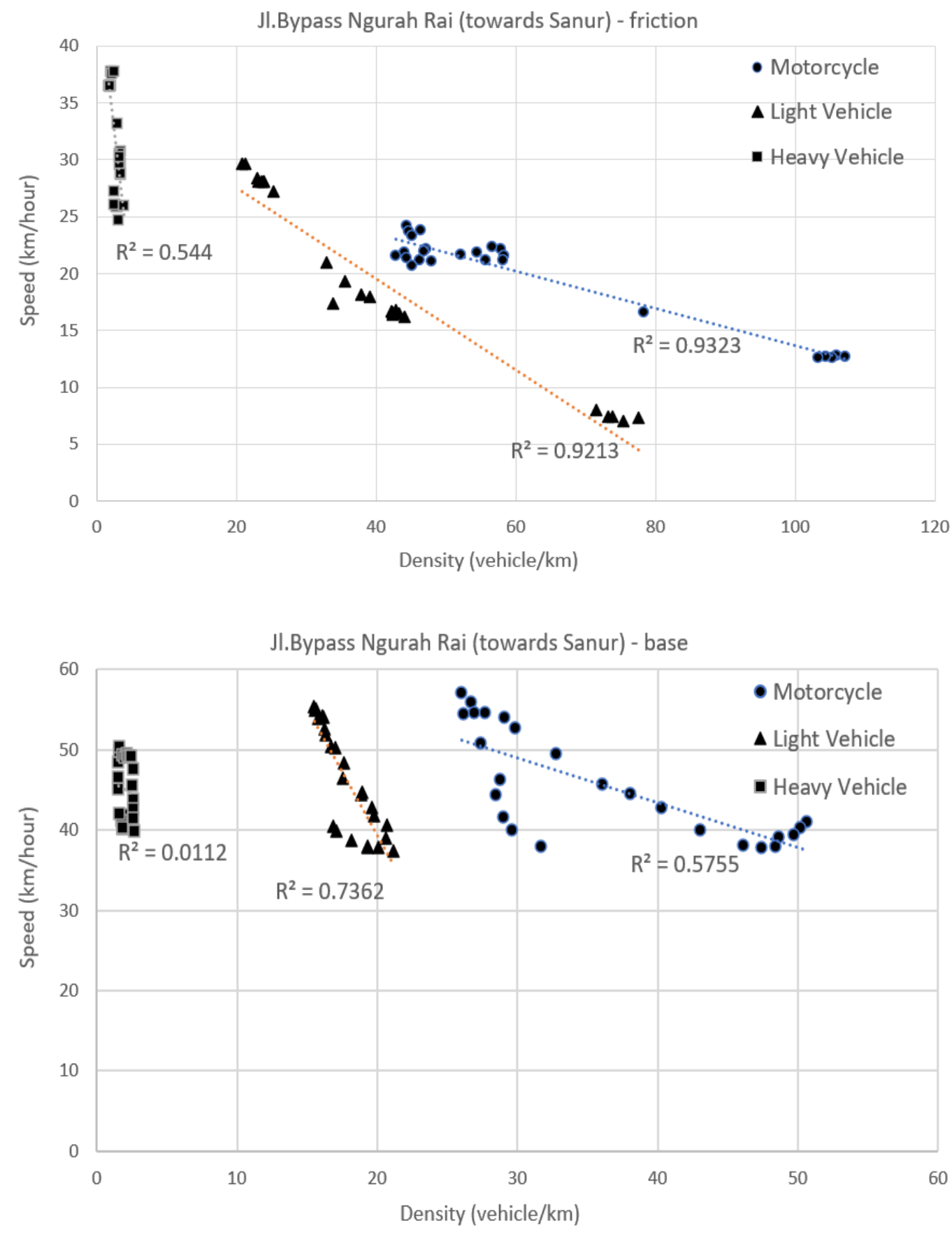

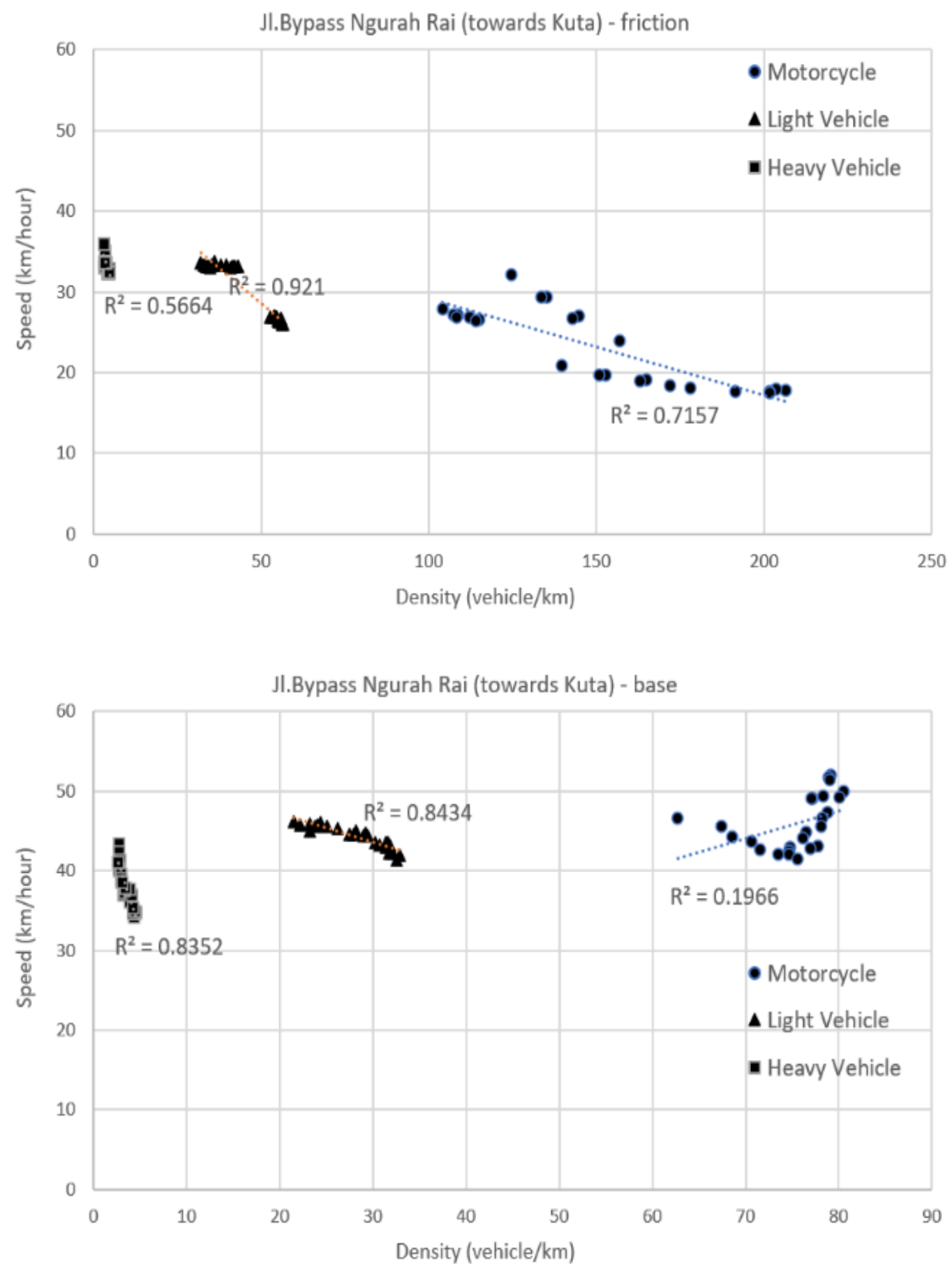

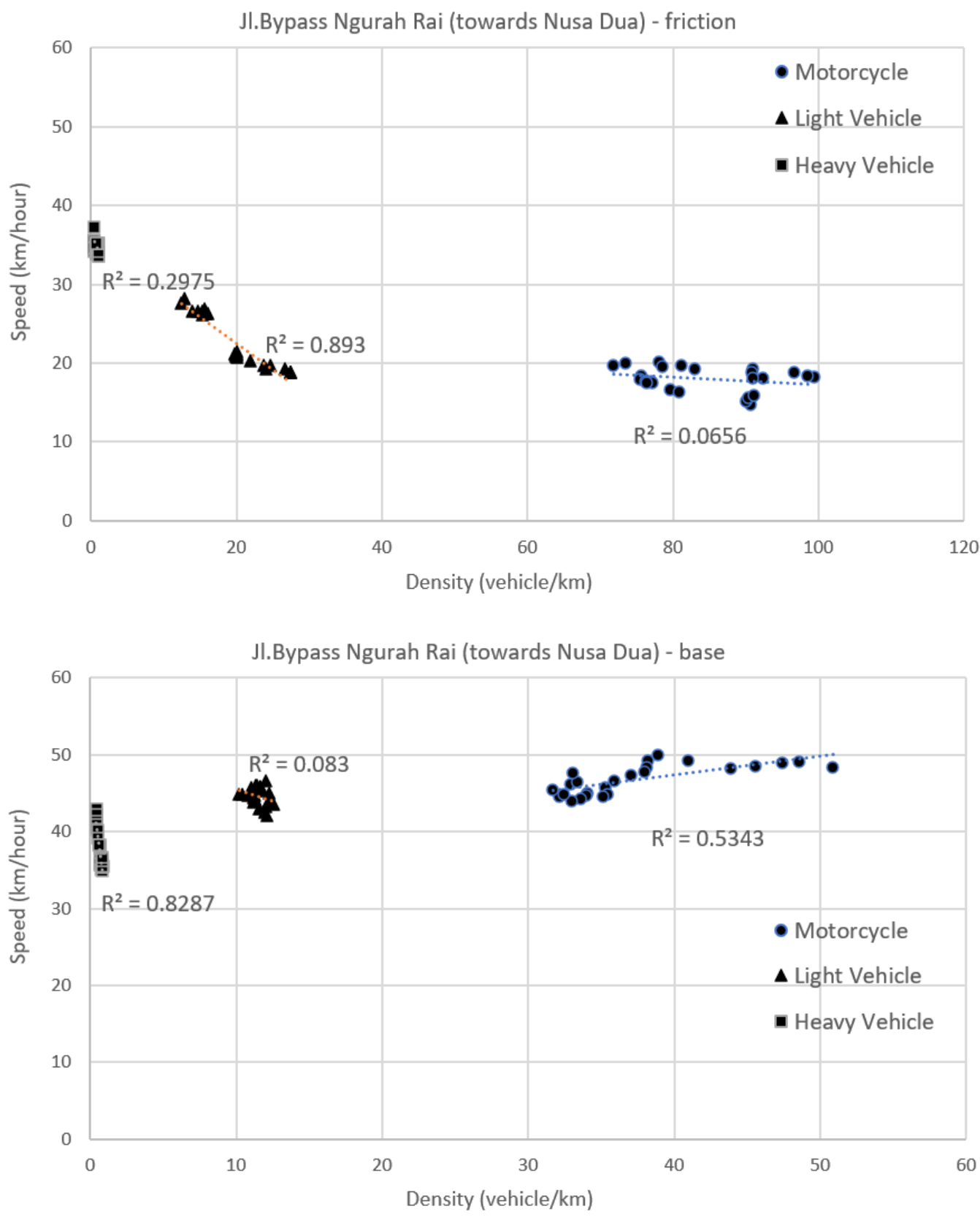

Figure 1. $\mathrm{R}^{2}$ of Speed-Density Model on Observed Road Segments with and without Side Frictions

Table 6. Free Flow Speed with and without Roadside Frictions

\begin{tabular}{|c|c|c|c|}
\hline Road Segments & Motorcycle (km/hour) & Light Vehicle km/hour) & Heavy Vehicle (km/hour) \\
\hline Jl. Bypass Ngurah Rai (towards Sanur) - friction & 55 & 65 & 65 \\
\hline Jl. Bypass Ngurah Rai (towards Kuta) - friction & 60 & 65 & 60 \\
\hline Jl. Bypass Ngurah Rai (towards Nusa Dua) - friction & 55 & 65 & 55 \\
\hline Jl. Bypass Ngurah Rai (towards Sanur) - base & 95 & 95 & 85 \\
\hline Jl. Bypass Ngurah Rai (towards Kuta) - base & 80 & 70 & 65 \\
\hline Jl. Bypass Ngurah Rai (towards Nusa Dua) - base & 85 & 80 & 60 \\
\hline
\end{tabular}


Subsequently, (4) becomes:

$\mathrm{V}_{\mathrm{i}}=\mathrm{a}_{\mathrm{oi}}-\mathrm{a}_{\mathrm{mc}} \cdot\left(\mathrm{n}_{\mathrm{mc}} / \mathrm{V}_{\mathrm{mc}}\right)-\mathrm{a}_{\mathrm{lv}} \cdot\left(\mathrm{n}_{\mathrm{lv}} / \mathrm{V}_{\mathrm{lv}}\right)-\mathrm{a}_{\mathrm{hv}} \cdot\left(\mathrm{n}_{\mathrm{hv}} / \mathrm{V}_{\mathrm{hv}}\right)$

The cumulative density functions (CDFs) shown in Figure 2 are used to determine the free-flow speed for each mode on the observed road segment with and without speed frictions. The free-flow speeds ( $\mathrm{km} /$ hour) shown in Table 6 are subsequently converted to meters per second.

Based on the SSR analysis, the speed of each type of vehicles dominantly is not normally distributed. However, the vehicle speed is not only influenced by the speed of other vehicles, but also the traffic composition in the traffic stream [7]. Multiple linear regression models, therefore, are constructed to analyze the influence of these three categories of vehicles (MC, LV \& HV) on the speed of each vehicle.

Figure 2 and Table 6 are used for determining the constant $\mathrm{a}_{0}$ in the model. A total of 1296 data samples with and without side frictions consisting of 5-minute interval traffic data were used for model construction. The model is made up of three vehicle categories that travel down a four-lane divided road segment with and without side frictions in one direction. The simultaneous models from (6) to (23) are subsequently analyzed with t-stat values for each coefficient except $\mathrm{a}_{0}$, because it is fixed as free-flow speed. The output of speed models (6)-(23) shows that 10 out of the 18 models $(56 \%)$ have $\mathrm{R}^{2}$ values above $50 \%$. The multiple regression model is therefore appropriate to be used to analyze the influence of these types of vehicles on the speed of each vehicle. In addition, the models are used to determine the reduction in road capacity with and without side frictions. Considering entry and exit of vehicles from the road access points were dominantly the parameter of side friction, speed prediction models developed in this study can be used to determine the speed of traffic flow which is affected by this side friction parameter.

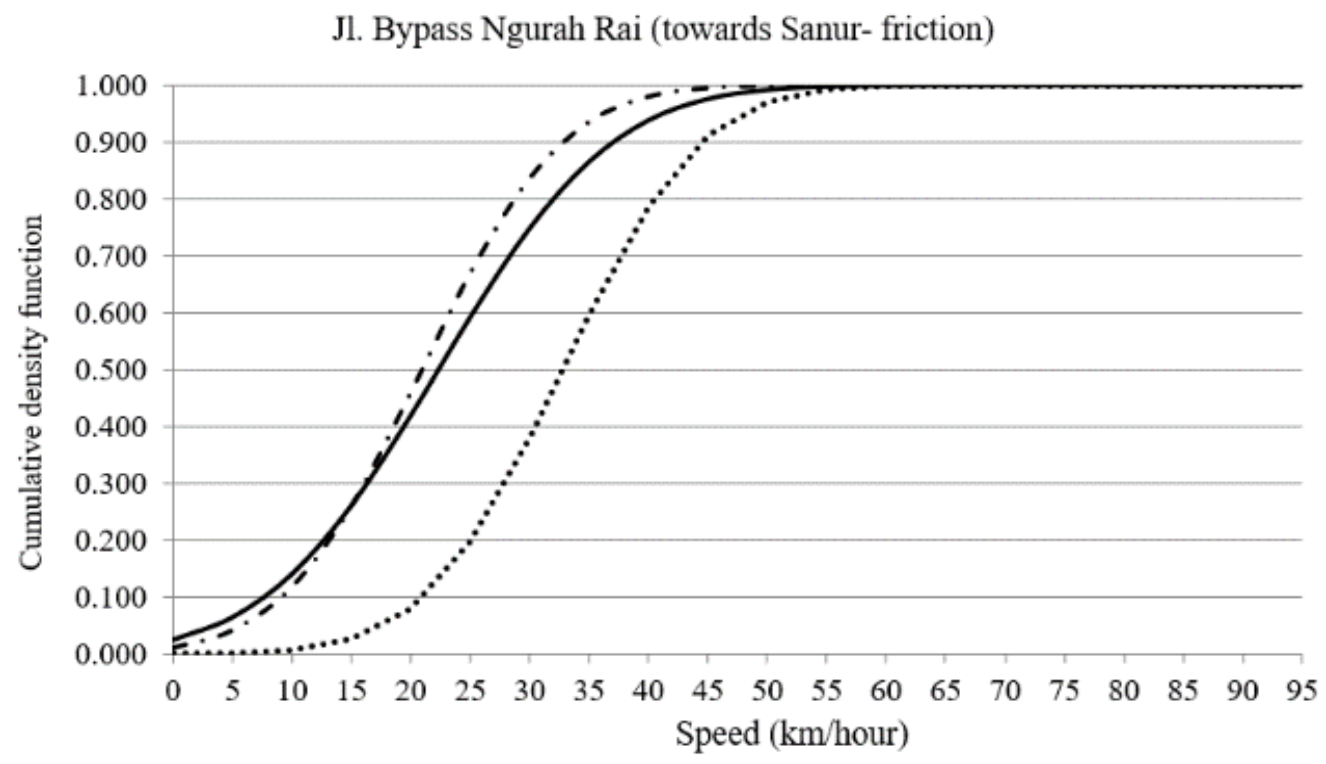

-.- Motorcycle —Light Vehicle ….... Heavy Vehicle 


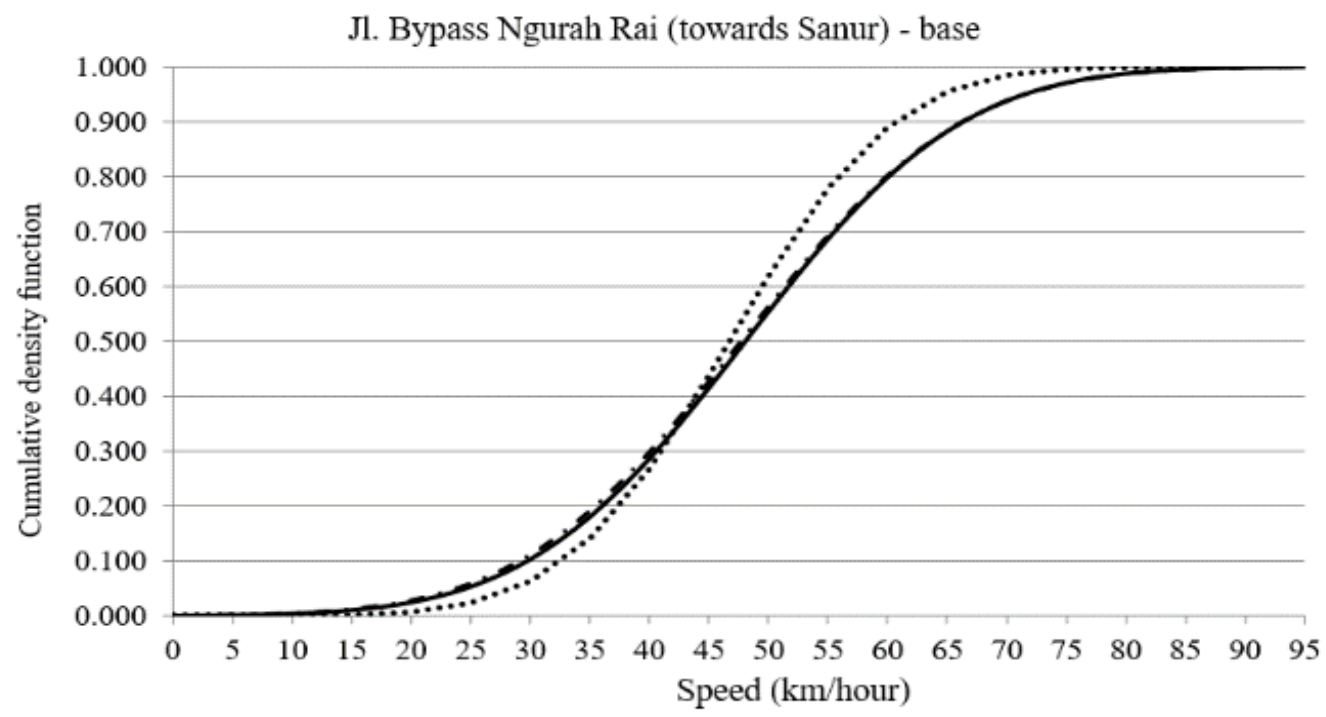

-.- Motorcycle —_Light Vehicle ....... Heavy Vehicle

Jl. Bypass Ngurah Rai (towards Kuta)-friction

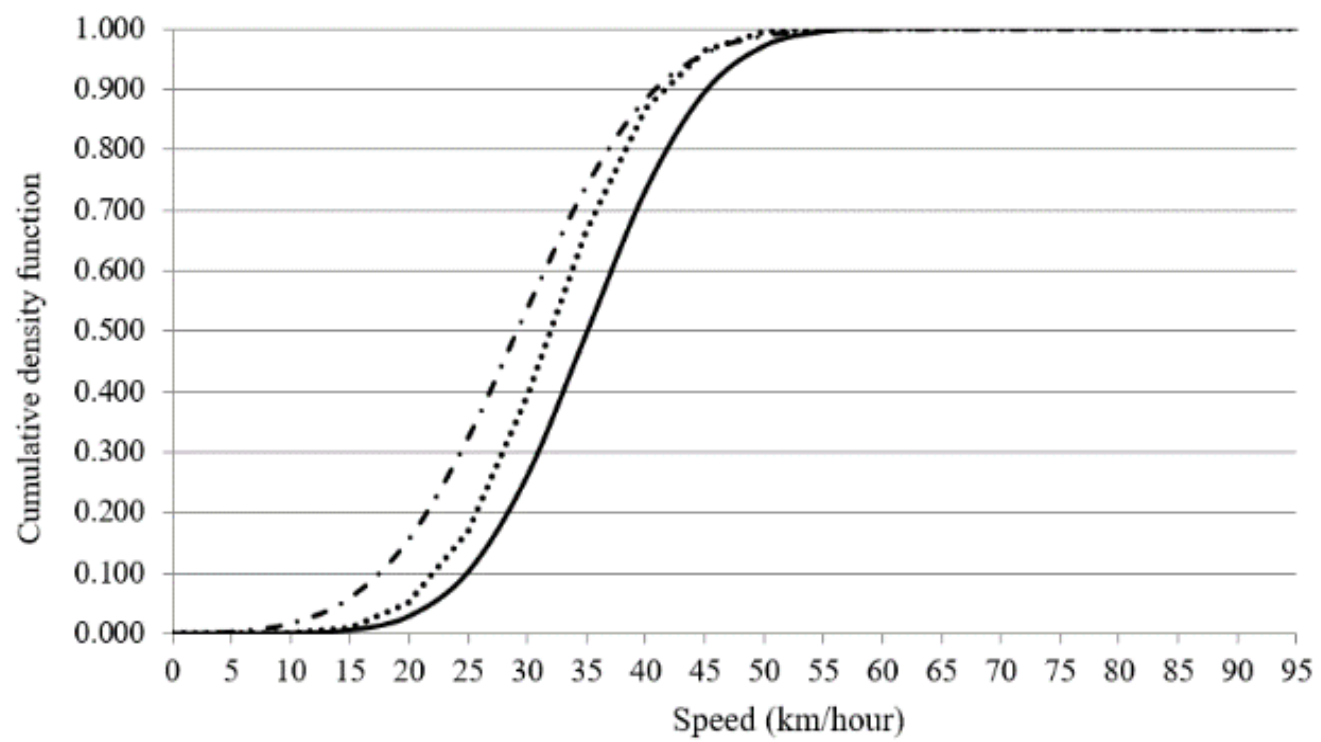

-.- Motorcycle —Light Vehicle ….... Heavy Vehicle 
Jl. Bypass Ngurah Rai (towards Kuta)-base

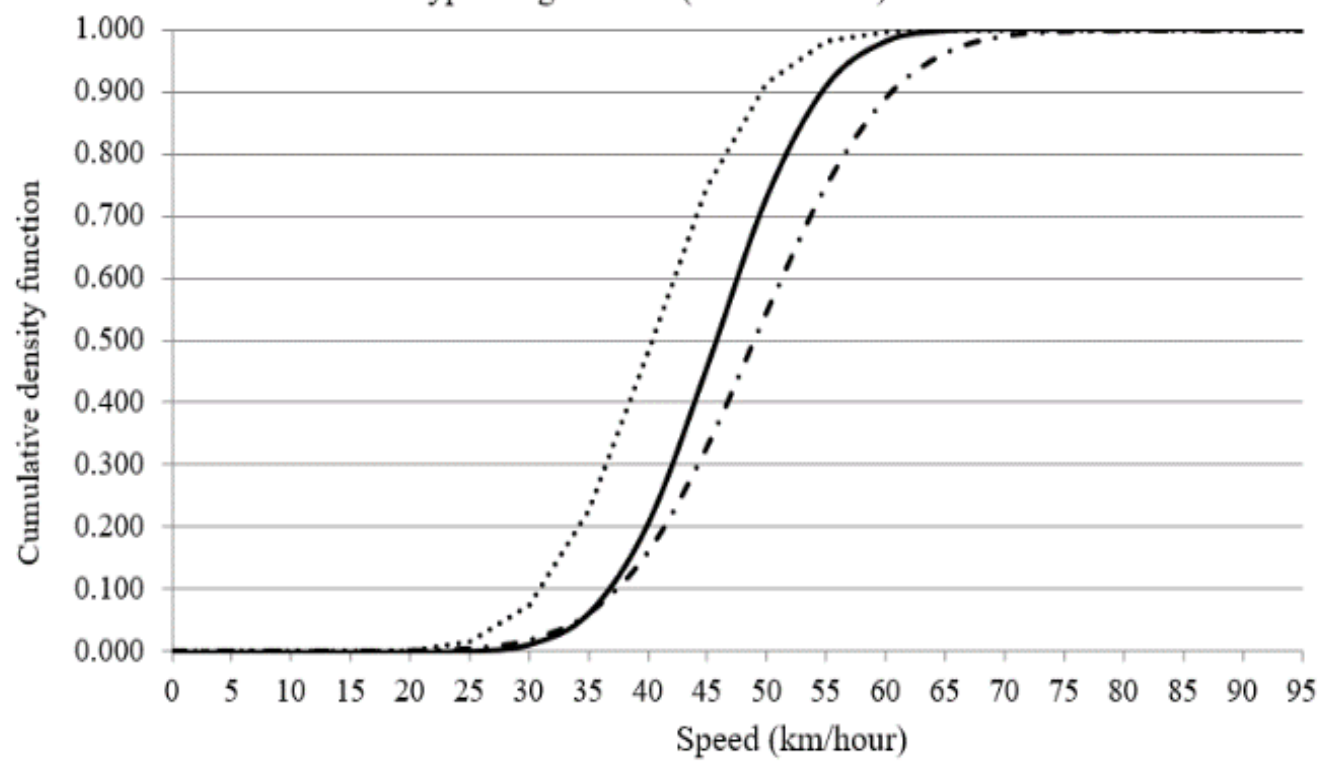

-.- Motorcycle —Light Vehicle ….... Heavy Vehicle

Jl. Bypass Ngurah Rai (towards Nusa Dua) - friction

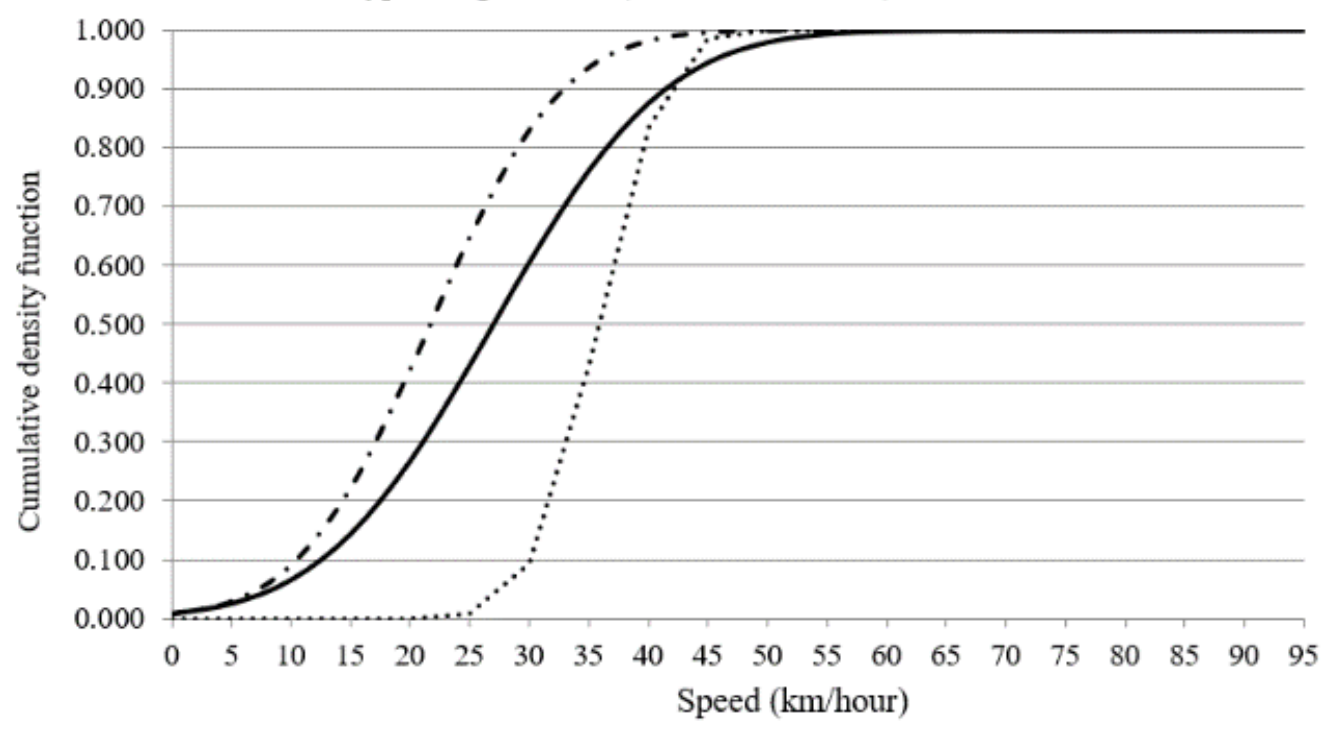

-.- Motorcycle _ Light Vehicle ….... Heavy Vehicle 


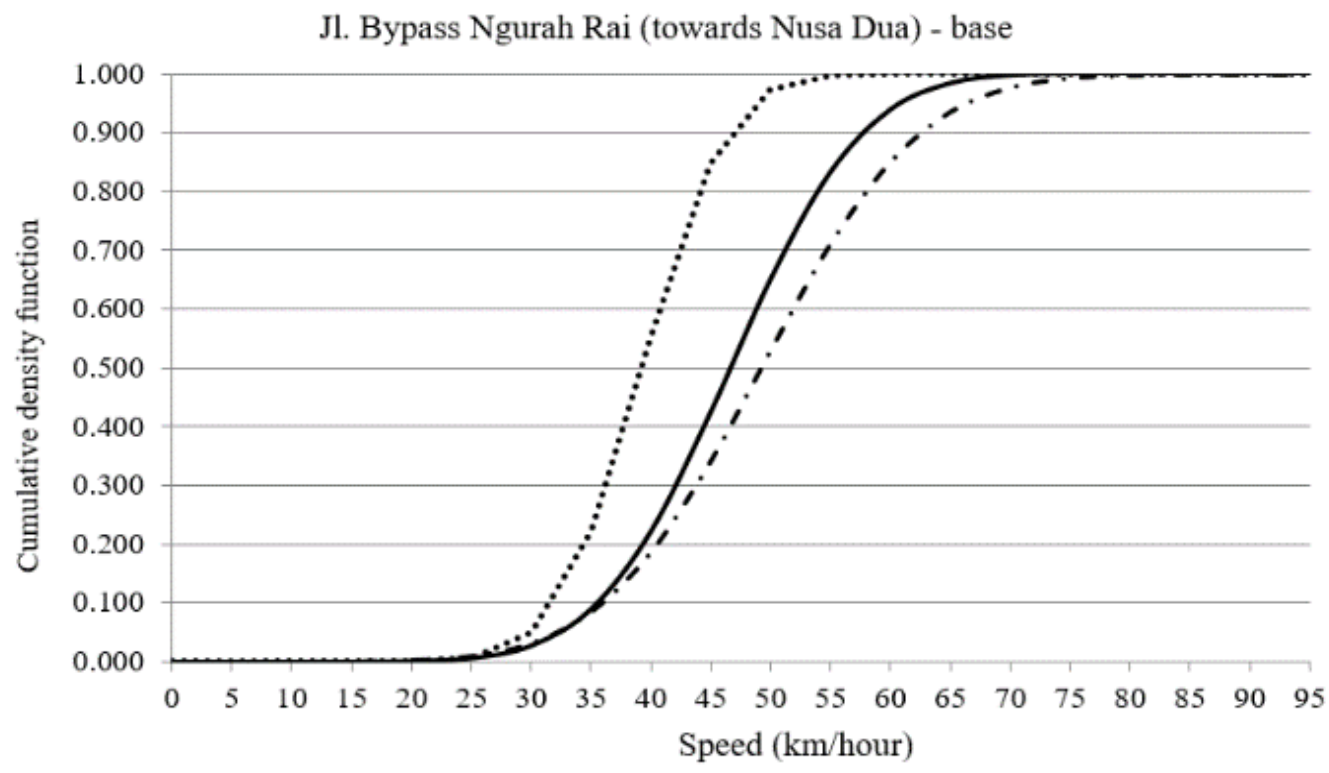

-.- Motorcycle —Light Vehicle

Heavy Vehicle

Figure 2. Cumulative Density Function on Observed Road Segment with and without Side Frictions

Speed models of Jl. Bypass Ngurah Rai (towards Sanur) are as follows:

$\begin{array}{lll}\mathrm{V}_{\mathrm{mc}(\mathrm{f})}=15.28-0.215 . \mathrm{K}_{\mathrm{mc}}-0.553 . \mathrm{K}_{\mathrm{lv}}-0.268 . \mathrm{K}_{\mathrm{hv}} & & \\ \left(\mathrm{R}^{2}=0.34\right) & (1.49) & (3.69) \\ \mathrm{V}_{\mathrm{lv}(\mathrm{f})}=18.06-0.125 . \mathrm{K}_{\mathrm{mc}}-0.039 . \mathrm{K}_{\mathrm{lv}}-0.341 . \mathrm{K}_{\mathrm{hv}} & & \\ \left(\mathrm{R}^{2}=0.12\right) & (0.75) & (0.23) \\ \mathrm{V}_{\mathrm{hv}(\mathrm{f})}=18.06-0.049 . \mathrm{K}_{\mathrm{mc}}-0.011 . \mathrm{K}_{\mathrm{lv}}-0.587 . \mathrm{K}_{\mathrm{hv}} & & \\ \left(\mathrm{R}^{2}=0.35\right) & (0.34) & (0.08) \\ \mathrm{V}_{\mathrm{mc}(\mathrm{b})}=26.39-0.426 . \mathrm{K}_{\mathrm{mc}}-0.422 . \mathrm{K}_{\mathrm{lv}}-0.082 . \mathrm{K}_{\mathrm{hv}} & & \\ \left(\mathrm{R}^{2}=0.53\right) \quad(3.23) & (3.14) \\ \mathrm{V}_{\left.\mathrm{lv}(\mathrm{b})=26.39-0.294 . \mathrm{K}_{\mathrm{mc}}-0.689 . \mathrm{K}_{\mathrm{lv}}-0.074 . \mathrm{K}_{\mathrm{hv}}\right)} & & \\ \left(\mathrm{R}^{2}=0.75\right) & (3.08) & \\ \mathrm{V}_{\mathrm{hv}(\mathrm{b})}=23.61-0.356 . \mathrm{K}_{\mathrm{mc}}-0.394 . \mathrm{K}_{\mathrm{lv}}-0.330 . \mathrm{K}_{\mathrm{hv}} & & \\ \left(\mathrm{R}^{2}=0.58\right) & (2.87)\end{array}$

Speed models of Jl. Bypass Ngurah Rai (towards Kuta) are as follows:

$\mathrm{V}_{\mathrm{mc}(\mathrm{f})}=16.67-0.762 . \mathrm{K}_{\mathrm{mc}}-0.239 . \mathrm{K}_{\mathrm{lv}}-0.199 . \mathrm{K}_{\mathrm{hv}}$
$\left(\mathrm{R}^{2}=0.70\right) \quad(7.09)$
$\mathrm{V}_{\mathrm{lv}(\mathrm{f})}=18.06-0.027 . \mathrm{K}_{\mathrm{mc}}-0.820 . \mathrm{K}_{\mathrm{lv}}-0.103 . \mathrm{K}_{\mathrm{hv}}$
$\left(\mathrm{R}^{2}=0.74\right)$
$\mathrm{V}_{\mathrm{hv}(\mathrm{f})}=16.67-0.250 . \mathrm{K}_{\mathrm{mc}}-0.157 . \mathrm{K}_{\mathrm{lv}}-0.494 . \mathrm{K}_{\mathrm{hv}}$
$\left(\mathrm{R}^{2}=0.43\right) \quad(1.68)$
$\mathrm{V}_{\mathrm{mc}(\mathrm{b})}=22.22-0.615 . \mathrm{K}_{\mathrm{mc}}-0.373 . \mathrm{K}_{\mathrm{lv}}-0.264 . \mathrm{K}_{\mathrm{hv}}$
$\left(\mathrm{R}^{2}=0.69\right)$
$\mathrm{V}_{\mathrm{lv}(\mathrm{b})}=19.44-0.457 . \mathrm{K}_{\mathrm{mc}}-0.614 . \mathrm{K}_{\mathrm{lv}}-0.033 . \mathrm{K}_{\mathrm{hv}}$
$\left(\mathrm{R}^{2}=0.64\right)$
$\mathrm{V}_{\mathrm{hv}(\mathrm{b})}=18.06-0.345 . \mathrm{K}_{\mathrm{mc}}-0.226 . \mathrm{K}_{\mathrm{lv}}-0.439 . \mathrm{K}_{\mathrm{hv}}$
$\left(\mathrm{R}^{2}=0.45\right)$


Speed models of Jl. Bypass Ngurah Rai (towards Nusa Dua) are as follows:

$$
\begin{aligned}
& \mathrm{V}_{\mathrm{mc}(\mathrm{f})}=15 \cdot 28-0.774 . \mathrm{K}_{\mathrm{mc}}-0.278 . \mathrm{K}_{\mathrm{lv}}-0.028 . \mathrm{K}_{\mathrm{hv}} \\
& \begin{array}{l}
\left(\mathrm{R}^{2}=0.87\right) \\
\mathrm{V}_{\mathrm{lv}(\mathrm{f})}=18.06-0.038 . \mathrm{K}_{\mathrm{mc}}-0.679 . \mathrm{K}_{\mathrm{lv}}-0.134 . \mathrm{K}_{\mathrm{hv}}
\end{array} \\
& \left(\mathrm{R}^{2}=0.48\right) \quad(0.17) \\
& \mathrm{V}_{\mathrm{hv}(\mathrm{f})}=15.28-0.480 . \mathrm{K}_{\mathrm{mc}}-0.318 . \mathrm{K}_{\mathrm{lv}}-0.489 . \mathrm{K}_{\mathrm{hv}} \\
& \left(\mathrm{R}^{2}=0.28\right) \\
& \text { (1.79) } \\
& \mathrm{V}_{\mathrm{mc}(\mathrm{b})}=23 \cdot 61-0.708 \cdot \mathrm{K}_{\mathrm{mc}}-0.354 \cdot \mathrm{K}_{\mathrm{lv}}-0.331 . \mathrm{K}_{\mathrm{hv}} \\
& \mathrm{V}_{\mathrm{lv}(\mathrm{b})}=22.22-0.581 \cdot \mathrm{K}_{\mathrm{mc}}-0.524 \cdot \mathrm{K}_{\mathrm{lv}}-0.324 . \mathrm{K}_{\mathrm{hv}} \\
& \left(\mathrm{R}^{2}=0.62\right) \\
& \mathrm{V}_{\mathrm{hv}(\mathrm{b})}=16.67-0.184 . \mathrm{K}_{\mathrm{mc}}-0.234 \cdot \mathrm{K}_{\mathrm{lv}}-0.381 . \mathrm{K}_{\mathrm{hv}} \\
& \left(\mathrm{R}^{2}=0.21\right) \\
& \text { (1.08) }
\end{aligned}
$$

\begin{tabular}{|c|c|c|c|c|}
\hline Road Segments & Type of Vehicle & MC & $\mathbf{L V}$ & HV \\
\hline \multirow{3}{*}{ Jl. Bypass Ngurah Rai (towards Sanur) - friction } & $\mathrm{MC}\left(\mathrm{R}^{2}=0.34\right)$ & & & \\
\hline & $\mathrm{LV}\left(\mathrm{R}^{2}=0.12\right)$ & & & \\
\hline & $\mathrm{HV}\left(\mathrm{R}^{2}=0.35\right)$ & & & \\
\hline \multirow{3}{*}{ Jl. Bypass Ngurah Rai (towards Kuta) - friction } & $\mathrm{MC}\left(\mathrm{R}^{2}=0.70\right)$ & V & $\mathrm{V}$ & $\mathrm{V}$ \\
\hline & $\mathrm{LV}\left(\mathrm{R}^{2}=0.74\right)$ & & $\mathrm{V}$ & \\
\hline & $\mathrm{HV}\left(\mathrm{R}^{2}=0.43\right)$ & & & \\
\hline \multirow{3}{*}{$\begin{array}{l}\text { Jl. Bypass Ngurah Rai (towards Nusa Dua) - } \\
\text { friction }\end{array}$} & $\mathrm{MC}\left(\mathrm{R}^{2}=0.87\right)$ & V & $\mathrm{V}$ & \\
\hline & $\operatorname{LV}\left(R^{2}=0.48\right)$ & & & \\
\hline & $\mathrm{HV}\left(\mathrm{R}^{2}=0.28\right)$ & & & \\
\hline \multirow{3}{*}{ Jl. Bypass Ngurah Rai (towards Sanur) - base } & $\mathrm{MC}\left(\mathrm{R}^{2}=0.53\right)$ & $\mathrm{V}$ & $\mathrm{V}$ & \\
\hline & $\mathrm{LV}\left(\mathrm{R}^{2}=0.75\right)$ & V & $\mathrm{V}$ & \\
\hline & $\mathrm{HV}\left(\mathrm{R}^{2}=0.58\right)$ & $\mathrm{V}$ & $\mathrm{V}$ & V \\
\hline \multirow{3}{*}{ Jl. Bypass Ngurah Rai (towards Kuta) - base } & $\mathrm{MC}\left(\mathrm{R}^{2}=0.69\right)$ & $\mathrm{V}$ & $\mathrm{V}$ & $\mathrm{V}$ \\
\hline & $\mathrm{LV}\left(\mathrm{R}^{2}=0.64\right)$ & V & $\mathrm{V}$ & \\
\hline & $\mathrm{HV}\left(\mathrm{R}^{2}=0.45\right)$ & & & \\
\hline \multirow{3}{*}{$\begin{array}{l}\text { Jl. Bypass Ngurah Rai (towards Nusa Dua) - } \\
\text { base }\end{array}$} & $\mathrm{MC}\left(\mathrm{R}^{2}=0.63\right)$ & $\mathrm{V}$ & $\mathrm{V}$ & $\mathrm{V}$ \\
\hline & $\mathrm{LV}\left(\mathrm{R}^{2}=0.62\right)$ & V & $\mathrm{V}$ & $\mathrm{V}$ \\
\hline & $\mathrm{HV}\left(\mathrm{R}^{2}=0.21\right)$ & & & \\
\hline
\end{tabular}

Table 7. The Influence of the Vehicle on the Speed of Other Vehicles 
Table 7 is a matrix showing the influence of the presence and speed of the motorized vehicle on each vehicle category in conditions with and without side frictions. The speed effect analysis is determined with a confidence interval of at least $90 \%$ (t-stats critical value of 1.64). In the condition that there are side frictions for these models whose confidence levels are above $50 \%$, the speed of the motorcycle is significantly affected by the presence and speed of other motorcycles and light vehicles. In conditions without side frictions, for the model whose confidence levels are above $50 \%$, the speed of a motorcycle is significantly affected by the presence and speed of all modes. Meanwhile, the speed of light vehicles is significantly affected by the presence and speed of motorcycles and other light vehicles. Considering the heavy vehicle speed models have low confidence intervals (below 50\%), the presence of motorized vehicles on the speed selection of heavy vehicles on arterial roads needs to be investigated in further studies.

\subsection{Passenger Car Equivalent and Speed-Flow Model}

Table 8 shows that the projection area of these three categories of motorized vehicles is used to evaluate the passenger car equivalent (PCE). These PCE values were used for the three-vehicle categories to convert heterogeneous traffic flows into homogeneous ones.

Table 8. Passenger Car Equivalence

\begin{tabular}{|c|c|c|c|c|c|c|c|c|c|}
\hline \multirow{2}{*}{ Road Segments } & \multirow{2}{*}{$\begin{array}{c}\mathbf{V}_{\mathrm{MC}} \\
(\mathbf{k m} / \mathbf{h})\end{array}$} & \multirow{2}{*}{$\begin{array}{c}V_{L V} \\
(\mathbf{k m} / \mathbf{h})\end{array}$} & \multirow{2}{*}{$\begin{array}{c}\mathbf{V}_{\mathrm{HV}} \\
(\mathbf{k m} / \mathbf{h})\end{array}$} & \multirow{2}{*}{$\begin{array}{l}\mathbf{A}_{\mathrm{MC}} \\
\left(\mathbf{m}^{2}\right)\end{array}$} & \multirow{2}{*}{$\begin{array}{l}\mathbf{A}_{\mathbf{L V}} \\
\left(\mathbf{m}^{2}\right)\end{array}$} & \multirow{2}{*}{$\begin{array}{l}\mathbf{A}_{\mathbf{H V}} \\
\left(\mathbf{m}^{2}\right)\end{array}$} & \multicolumn{3}{|c|}{ Average PCU Values } \\
\hline & & & & & & & MC & LV & HV \\
\hline J1. Bypass Ngurah Rai (towards Sanur)-friction & 16 & 11 & 29 & 1.2 & 12.18 & 31.46 & 0.07 & 1 & 0.98 \\
\hline J1. Bypass Ngurah Rai (towards Kuta)-friction & 23 & 28 & 30 & 1.2 & 12.18 & 31.46 & 0.12 & 1 & 2.41 \\
\hline Jl. Bypass Ngurah Rai (towards Nusa Dua)-friction & 18 & 19 & 35 & 1.2 & 12.18 & 31.46 & 0.10 & 1 & 1.40 \\
\hline J1. Bypass Ngurah Rai (towards Sanur)-base & 43 & 45 & 44 & 1.2 & 12.18 & 31.46 & 0.10 & 1 & 2.64 \\
\hline Jl. Bypass Ngurah Rai (towards Kuta)-base & 47 & 45 & 39 & 1.2 & 12.18 & 31.46 & 0.09 & 1 & 2.98 \\
\hline Jl. Bypass Ngurah Rai (towards Nusa Dua)-base & 47 & 45 & 39 & 1.2 & 12.18 & 31.46 & 0.09 & 1 & 2.78 \\
\hline
\end{tabular}

Table 9. Speed-Density Model

\begin{tabular}{|c|c|c|c|}
\hline Road Segments & Speed-Density Model & $\begin{array}{l}\text { Max. Capacity (Qmax } \\
\text { (pcu/hour)) }\end{array}$ & $\begin{array}{c}\text { Speed at Qmax }\left(V_{\text {Qmax }}\right. \\
(\mathrm{km} / \mathrm{hour}))\end{array}$ \\
\hline $\begin{array}{l}\text { Jl. Bypass Ngurah Rai (towards Sanur) - } \\
\text { friction }\end{array}$ & $\mathrm{Vs}=32 . \mathrm{D}-\left(0.278 . \mathrm{D}^{2}\right)$ & 919 & 15 \\
\hline $\begin{array}{l}\text { Jl. Bypass Ngurah Rai (towards Kuta) - } \\
\text { friction }\end{array}$ & $\mathrm{Vs}=50 . \mathrm{D}-\left(0.282 . \mathrm{D}^{2}\right)$ & 2216 & 25 \\
\hline $\begin{array}{l}\text { Jl. Bypass Ngurah Rai (towards Nusa Dua) } \\
\text { - friction }\end{array}$ & $\mathrm{Vs}=39 . \mathrm{D}-\left(0.592 . \mathrm{D}^{2}\right)$ & 637 & 21 \\
\hline $\begin{array}{l}\text { Jl. Bypass Ngurah Rai (towards Sanur) - } \\
\text { base }\end{array}$ & $\mathrm{Vs}=113 . \mathrm{D}-\left(2.521 . \mathrm{D}^{2}\right)$ & 1252 & 63 \\
\hline $\begin{array}{l}\text { Jl. Bypass Ngurah Rai (towards Kuta) - } \\
\text { base }\end{array}$ & $\mathrm{Vs}=59 . \mathrm{D}-\left(0.336 . \mathrm{D}^{2}\right)$ & 2588 & 29 \\
\hline $\begin{array}{l}\text { Jl. Bypass Ngurah Rai (towards Nusa Dua) } \\
\text { - base }\end{array}$ & $\mathrm{Vs}=74 . \mathrm{D}-\left(1.744 . \mathrm{D}^{2}\right)$ & 782 & 39 \\
\hline
\end{tabular}



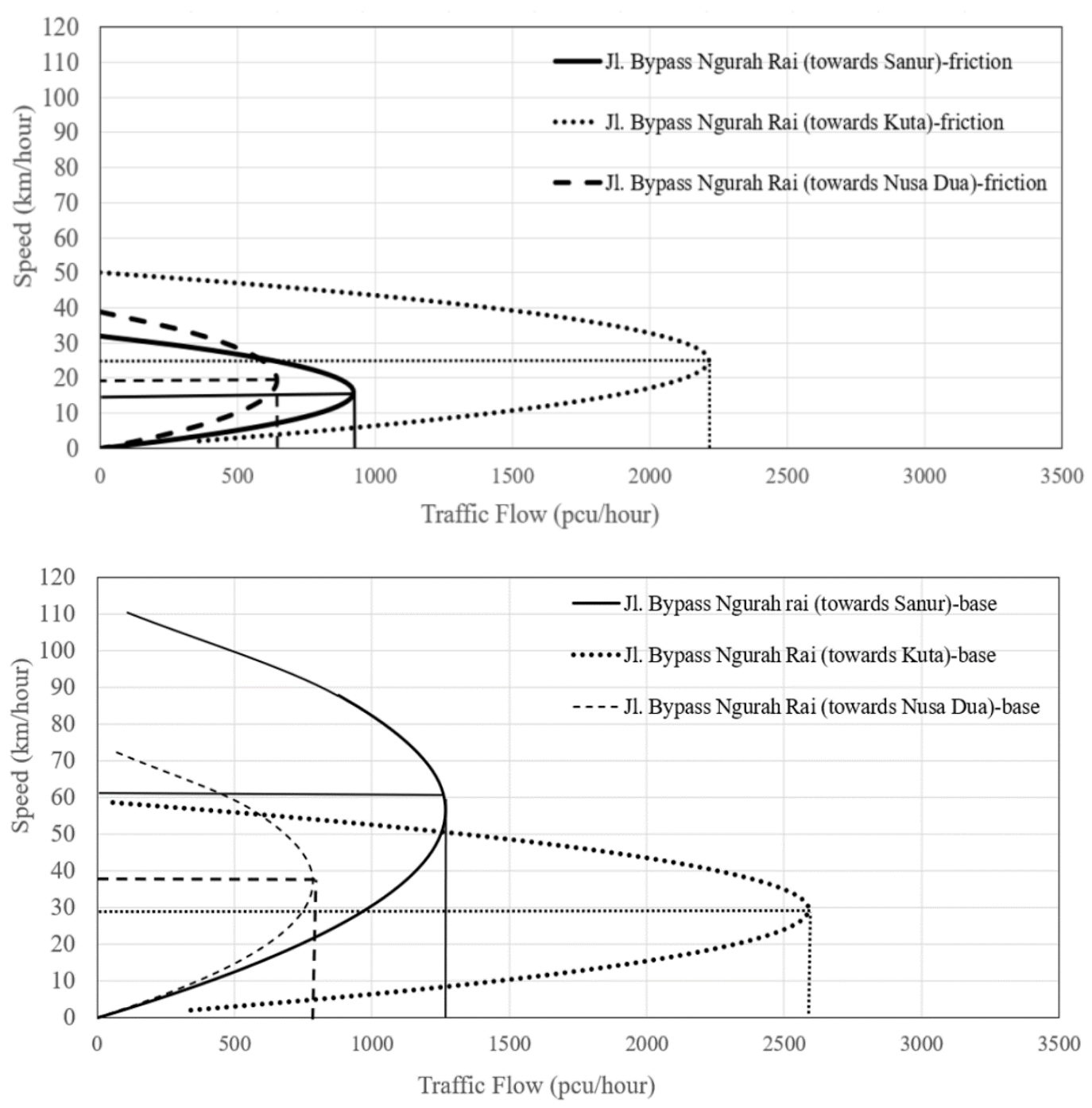

Figure 3. Speed-Flow Model with and without Side Frictions

The mean values of PCE are derived from Table 1 and (1). Table 8 shows that there is a large variation in the estimated value of PCE for, in particular, heavy vehicles (HV) in the various observation segments. Even for the close observation segment, the PCE value of HV varies from one interval to another, as shown in Table 8.

Using the PCE values in Table 8 , the data from the observation of traffic parameters are converted into passenger car units (PCU), namely from heterogeneous traffic conditions to homogeneous ones. Using these PCE values, the speed-density model was rearranged to obtain a speed-flow model based on the Greenshields model. Table 9 shows the most suitable speed-density relationship model for each observation segment with (friction) and without (base) side frictions.

\subsection{Road Capacity Reduction Analysis}

For detailed calculations in the preparation of the model in Table 9, the reader can refer to a previous study [23]. Table 9 shows that there is a decrease in maximum capacity (pcu/hour) in the range of $14.37 \%-26.60 \%$ and a decrease in speed in the range of $13.79 \%-76.19 \%$ due to side frictions. Considering the survey was conducted during a pandemic, the traffic volume may not be in usual conditions. This study shows that capacity reduction due to entry and exit of vehicles from surrounding is found higher than pedestrian activity [6] but lower than bus stops and on-street parking [16].

The decrease in capacity and speed is considered to be an indicator of a significant side frictions problem on arterial roads in tourism areas in Bali. Given that the biggest side frictions are due to the entry and exit of vehicles from surroundings, the road access control policy is needed on these arterial roads.

Figure 3 shows that there are saturated or congested traffic conditions and the segment reaches the maximum capacity $\left(\mathrm{Q}_{\max }(\mathrm{pcu} / \mathrm{hour})\right)$ when the flows on Jl. Bypass Ngurah Rai (towards Sanur), Jl. Bypass Ngurah Rai (towards Kuta) and Jl. Bypass Ngurah Rai (towards Nusa Dua) is at 919 pcu/hour, $2216 \mathrm{pcu} / \mathrm{hour}$, and $637 \mathrm{pcu} / \mathrm{hour}$ respectively in friction conditions and are at $1252 \mathrm{pcu} / \mathrm{hour}$, 
$2588 \mathrm{pcu} / \mathrm{hour}$, and $782 \mathrm{pcu} / \mathrm{hour}$ respectively in base conditions. A further increase in current results in a stop-and-go condition and a significantly reduced flow rate. The speeds at maximum capacity $\left(\mathrm{V}_{\mathrm{Qmax}}(\mathrm{km} / \mathrm{hour})\right)$ on $\mathrm{Jl}$. Bypass Ngurah Rai (towards Sanur), Jl. Bypass Ngurah Rai (towards Kuta) and Jl. Bypass Ngurah Rai (towards Nusa Dua) are $15 \mathrm{~km} / \mathrm{h}, 25 \mathrm{~km} / \mathrm{h}$ and $21 \mathrm{~km} / \mathrm{h}$ respectively in friction conditions and are $63 \mathrm{~km} / \mathrm{h}, 29 \mathrm{~km} / \mathrm{h}$ and $39 \mathrm{~km} / \mathrm{h}$ respectively in base conditions respectively.

In line with past studies in urban areas under mixed traffic conditions; the result of this study shows that there was a significant impact of side friction on vehicular speed and could also bring about the extent of the impact of individual factors on speed $[4,6,16]$. The existence of unrestricted access on arterial roads and which are trip generators significantly reduces vehicle speed and thereby reduces traffic speed. Reducing the current speed leads to a significant decrease in maximum capacity. This capacity reduction depends on the proportion of trip generation, i.e. entry and exit of vehicles from the surrounding. The results of this study suggest the need for policy focus to reduce the impact of access on arterial roads which significantly affect traffic operations on urban roads.

Further, the road access policy, particularly in urban areas/ tourism areas, indeed needs to be implemented to achieve road performance that is following the plan in serving the function of traffic movement. These arrangements need to be made through simple criteria so that they can easily be implemented on-site.

\section{Conclusions}

This study aims to develop speed-flow models to analyze the effect of side frictions on the performance of arterial roads. This research was conducted on four lanes two-way divided arterial roads (4/2 D) in tourism areas in Bali. The roadside friction event is dominated by the entry and exit of vehicles from the road access points. Considering the study results, this research suggests updating the formulation of MKJI, in particular side frictions. The event of side frictions significantly happened on all types of roads and influenced road performances.

The study results also showed that there was a large variation in the estimation of the PCE value for heavy vehicles (HV). Even for the same observation segment, this value varies from one interval to another due to the proportion of $\mathrm{HV}$ varies on the observed roads. The speed of the motorcycle is significantly affected by the presence and speed of other motorcycles and light vehicles. In base conditions, the speed of the motorcycle is significantly affected by the presence and speed of all types of vehicles. Meanwhile, the speed of light vehicles is significantly affected by the presence and speed of motorcycles and other light vehicles.

Due to side frictions, there was a decrease in capacity (pcu/hour) in the range of $14.37 \%-26.60 \%$ and a decrease in speed in the range of $13.79 \%-76.19 \%$. Considering the research was conducted during a pandemic, the traffic volume may not be in usual conditions. The decrease in capacity and speed, however, indicates a significant side friction problem on arterial roads in tourism areas. This study suggests the need for further studies related to the influence of motorized vehicles on the selection of heavy vehicle speed on arterial roads. In addition, the road control policy, particularly on roadside access is needed for these arterial roads.

\section{Acknowledgments}

This work was supported by the University of Udayana, Bali, Indonesia.

\section{REFERENCES}

[1] The Law of the Republic of Indonesia Number 38 of 2004 concerning Road, Jakarta, gove2004.

[2] The Law of the Republic of Indonesia Number 22 of 2009 concerning Road Traffic and Transportation, Jakarta, 2009.

[3] C.R. Patel, G.J. Joshi. Mixed traffic speed-flow behavior under influence of road side friction and non-motorized vehicles: a comparative study of arterial roads in India, International Journal of Civil, Environmental, Structural, Construction and Architectural Engineering, Vol.8, No.11, 1203-1209, 2014.

[4] S. Salini, S. George, R. Ashalatha. Effect of side frictions on traffic characteristics of urban arterials, Transportation Research Procedia, Vol.17, 636 - 643, 2016.

[5] S. Pal, S.K. Roy. Impact of roadside friction on travel speed and LOS of rural highways in India, Transportation in Developing Economies, Vol.2, No.9, 1-12, 2016.

[6] P. Gulivindala, A. Mehar. Analysis of side friction on urban arterials, Transport and Telecommunication, Vol.19, No.1, 21-30, 2018.

[7] P.M. Shah, N. Gupta. Analysis of speed parameters of mixed traffic flow on the sections of arterial streets (Jalandhar and Chandigarh Cities), Indian Journal of Science and Technology, Vol.9, No. 47, 1-6, 2016.

[8] R. Ibrahim, L.B. Zala, A.A. Amin. Individual vehicle speed modeling on urban arterials in mixed traffic conditions by using artificial neural network, International Research Journal of Engineering and Technology, Vol.5, No.5, 25682577, 2018.

[9] P. Kumar, S. Arkatkar. G. Joshi. New approach for estimating passenger car units on multilane urban roads with heterogeneous traffic conditions, Journal of Transportation Engineering, Part A: Systems, Vol.144, No.3, 1-14, 2018. 
[10] P.V. Suvin, C. Mallikarjuna. Modified generalized definitions for the traffic flow characteristics under heterogeneous, no-lane disciplined traffic streams, Transportation Research Procedia, Vol.34, 75-82, 2018

[11] S. Salini, R. Ashalatha. Analysis of traffic characteristics of urban roads under the influence of roadside frictions, Case Studies on Transport Policy, Vol.8, Issue 1, 94-100, 2020.

[12] Directorate General of Bina Marga. Indonesian Road Capacity Manual, Ministry of Public Works, Jakarta, 1997.

[13] Central Bureau of Statistics of Bali Province. Bali in Figures, Bali Provincial Government, Denpasar, 2018.

[14] A. Munawar, M.Z. Irawan, A.G. Fitrada. Developing Indonesian Highway Capacity Manual Based on Microsimulation Model (A Case of Urban Roads), In: Proceeding Transactions on Engineering Technologies: $25^{\text {th }}$ World Congress on Engineering, 153- 163, 2018.

[15] I. Adinarayana, N.C. Anil. The study exploration towards side friction influences by traffic performance measures on roads, International Journal of Science Engineering and Advance, Vol.5, No.11, 1024-1031, 2017.

[16] A.M. Rao, S. Velmurugan, K.M.V.N. Lakshmi. Evaluation of influence of roadside frictions on the capacity of roads in Delhi, India, Transportation Research Procedia, Vol.25, 4771-4782, 2017.

[17] S. Chandra, A. Mehar, S. Velmurugan. Effect of traffic composition on capacity of multilane highways, KSCE Journal of Civil Engineering, Vol.20, No.5, 2033-2040,
2015.

[18] S. Srikanth, A. Mehar. Estimation of equivalency units for vehicle types under mixed traffic conditions: multiple non-linear regression approach, International Journal of Technology, Vol.5, 820-829, 2017.

[19] Directorate General of Bina Marga. The Guidelines for Geometric Planning Procedures for Inter-City Roads, Ministry of Public Works, Jakarta, 1997.

[20] N. Roy, R. Roy, H. Talukdar, P. Saha. Effect of mixed traffic on capacity of two-lane roads: case study on Indian highways, Procedia Engineering, Vol.187, 53 - 58, 2017.

[21] L. Gautam, J.K. Jain. Study on mixed traffic flow behavior on arterial road, International Journal of Engineering Research and Technology, Vol.6, No.11, 1-7, 2018.

[22] A. Dhamaniya, S. Chandra. Influence of operating speed on capacity of urban arterial midblock sections, International Journal of Civil Engineering, Vol.15, No.7, 1053-1062, 2017.

[23] B.D. Greenshields. A Study of Traffic Capacity, In Proceeding $14^{\text {th }}$ Annual Meeting of the Highway Research Board, Washington, DC: Transportation Research Board, 448-477. 1935.

[24] M. Patkar, A. Dhamaniya. Influence of nonmotorized vehicles on speed characteristics and capacity of mixed motorized traffic of urban arterial midblock sections, Journal of Transportation, Engineering, Part A: Systems, Vol.146, No.4, 04020013, 2020. 